\title{
DNA Topoisomerase 2-Alpha
}

National Cancer Institute

\section{Source}

National Cancer Institute. DNA Topoisomerase 2-Alpha. NCI Thesaurus. Code C17801.

DNA topoisomerase 2-alpha (1531 aa, $174 \mathrm{kDa}$ ) is encoded by the human TOP2A gene.

This protein is involved in the modulation of DNA topology. 